\title{
Concrete Based on Recycled Aggregates for Their Use in Construction: Case of Goma (DRC)
}

\author{
Masika Muhiwa Grâce', Alinabiwe Nyamuhanga Ally', Muhindo Wa Muhindo Abdias², \\ Kubuya Binwa Patient ${ }^{1}$, Muhatikani Trésor ${ }^{1}$, Manjia Marcelline Blanche ${ }^{3}$, Ngapgue Francois ${ }^{4}$
}

${ }^{1}$ Department of Civil Engineering, Faculty of Applied Sciences and Technologies, UniversitéLibre des Pays des GrandsLacs, Goma, Democratic Republic of Congo

${ }^{2}$ Buildings and Publics Works Section, Institut du Bâtiment et des Travaux Publics, Butembo, Democratic Republic of Congo

${ }^{3}$ Department of Civil Engineering, National Advanced School of Engineering, University of Yaoundé 1, Yaoundé,

Cameroon

${ }^{4}$ Department of Civil Engineering, Fotso Victor University Institute of Technology, University of Dschang, Bandjoun,

Cameroon

Email: ir.alny111@gmail.com

How to cite this paper: Grâce, M.M., Ally, A.N., Abdias, M.W.M., Patient, K.B., Trésor, M., Blanche, M.M. and Francois, N. (2020) Concrete Based on Recycled Aggregates for Their Use in Construction: Case of Goma (DRC). Open Journal of Civil Engineering, 10, 226-238.

https://doi.org/10.4236/ojce.2020.103019

Received: May 19, 2020

Accepted: July 31, 2020

Published: August 3, 2020

Copyright (อ 2020 by author(s) and Scientific Research Publishing Inc. This work is licensed under the Creative Commons Attribution International License (CC BY 4.0).

http://creativecommons.org/licenses/by/4.0/ (c) (i) Open Access

\begin{abstract}
The following study is aimed at valorizing an important part of waste from building demolition, particularly concrete as a source of aggregates for their usage in new hydraulic concrete formulation. The experimental study mainly consisted of physical characterization of natural and recycled aggregates respectively and the impact of the latter on some properties of the new formulated concrete, actually their respective consistencies for fresh concrete and mechanical strength for the hardened one. The outcome of the study shows that the recycled aggregates are more heterogeneous and have a high capacity of water absorption, but which still respects the current standards of concrete. The need for additional water has been observed for recycled aggregates-based concrete so as to have the same workability. About the compressive strength, mechanical properties obviously show that, at 28 days from setting up, concretes from recycled aggregates can reach compressive strengths range between 20 and $25 \mathrm{MPa}$ without any sophisticated technology. So, these results show that we can efficiently contribute to the protection of environment by valorizing waste from concrete-based building demolition on the one hand; and the preservation of natural reserve on the other. And both advantages contribute to sustainable development overall goals.
\end{abstract}

\section{Keywords}

Demolition, Recycling, Water Absorption, Concrete, Mechanic Resistance 


\section{Introduction}

Waste from building demolition is found almost everywhere in streets, forests and in rivers. They are considered as a great source of nature pollution. Therefore, is can also be seen as a cause of environmental problems such as fauna and flora destruction, underground water pollution, saturation of public waste, unnecessary increase in additional sanitation water to be evacuated, nauseating garbage, insalubrity, flooding, etc. [1].

Recycling of such polluting waste by using it in new concrete formulation remains one of the possible solutions to that problem though Amor Ben Fraj et al., 2017 [2]; Wirquin et al., 2000 [3] as well as Courard L. et al. [4], assumed that usage of demolition materials as substitution aggregates is sometimes very difficult to realize since such materials are porous and so highly water absorbing.

The majority of concrete from buildings demolition-based recycled aggregates are used in road construction. Nevertheless, a better knowledge of its characteristics can contribute to development of that field of construction (Buyle-Bodin et al. 2002 [5] and Hussain et al. 2003 [6]). This can only be achieved by a deep knowledge of fresh concrete.

However, recycled aggregates could be used as building materials in confection of concrete when the size of the building fits with their respective characteristics. Therefore, this work is aimed to study the strength of concrete formulated by recycled aggregates in order to propose its domain of usage. In so doing, we hope to find a way of protecting the environment against the building demolition waste. The global objective of this study is to take profit from aggregates from concrete building demolition so as to perform new concrete products and contribute to environment protection by reducing building demolition waste in nature.

\section{Materials and Methods}

In this section, we present all tests which are necessary to describe, both qualitatively and quantitatively, the aggregates as well as the concrete. The most important characteristics for concrete were respectively their consistency and compressive strength at fresh and hardened state. The tests were conducted in the laboratory of the Université Libre des Pays des Grands Lacs. Materials that were used in this study are: aggregates (sand and gravels), water, and cement.

\subsection{Origin of Constituents}

\subsubsection{Aggregates}

Natural sand 0/5, from Lake Kivu, of density 1.36 and specific unit weight 2.5. Recycled sand 0/5, from concrete blocks fragmentation and sieving in order to obtain sand in conformity to the norm NF EN 933-1 [7]. Natural gravels 5/25, from crushing of basaltic rock. Recycled gravels 5/25 from concrete blocks fragmentation. 


\subsubsection{Water}

Water used form concrete formulation was from "Régie de Distribution d'Eau" (REGIDESO), the water distribution company in Goma.

\subsubsection{Cement}

The cement used is the Compound Portland Cement CEM II 32.5R RHINO produced in Kenya. Its characteristics are presented in Table 1.

\subsection{Experimentation}

In this section, we present tests on aggregates on the one hand, which include particle size analysis, sand equivalent and bulk unit weight; and on concrete on the other, which include consistency and compressive strength at fresh and hardened states respectively.

\subsubsection{Tests on Aggregates}

\section{1) Particle size analysis}

\section{a) Purpose}

Particle size composition is obtained by standardized particle size analysis NF EN 933-1 [7]. Particle size analysis is aimed to determine the grains weight distribution of aggregates according to their size by plotting a particle size curve.

\section{b) Principle}

Particle size analysis is carried out by dividing through a series of sievers the material into different granular classes of decreasing particle size. From that segregation, we obtain the mass of particles retained by the different sievers and passing through them. They are presented in terms of their respective ratios to the initial mass. The cumulated ratio of particles passing through a given siever is obtained by the expression (1).

$$
P_{j}(\%)=\left(1-\frac{\sum M_{i}^{r}}{M_{s}}\right) \cdot 100
$$

Table 1. Characteristics of the compound Portland cement used.

\begin{tabular}{|c|c|c|c|}
\hline Commercial name & & CEM II $32.5 \mathrm{R}$ cement & \\
\hline Color & & Gray & \\
\hline Specific density & & 3.1 & \\
\hline Bulkunit weight $\left(\mathrm{g} / \mathrm{cm}^{3}\right)$ & & 1.17 & \\
\hline Setting time & & 4 hours & \\
\hline Grains diameter & & $80 \mu \mathrm{m}$ & \\
\hline Specific area & & 3100 & \\
\hline Realresistance class at 28 days & & $32.5 \mathrm{MPa}$ & \\
\hline \multirow{2}{*}{ Constitutive element of cement } & Clinker & Gypsum & Pozzolana \\
\hline & $65 \%$ & $5 \%$ & $30 \%$ \\
\hline
\end{tabular}


With $\sum M_{i}^{r}$ : the mass of the particles retained by the siever $(i) ; 1 \leq i \leq j$ and $M_{s}$ the total dry of dry material sample.

For sand, from particle size analysis, we obtain the finesse module. This parameter characterizes sand size. Finesse module is obtained by the summation of the percentages of the particles retained on the different sievers of respective opennings $0.16,0.315,0.63,1.25,2.5$ and $5 \mathrm{~mm}$. It is preferable that the finesse module of sand for a motar and/or concrete be comprised between 2.2 and 2.8 .

c) Equipment

- A column of sievers

- Sievers vibrator

- A weighing machine

\section{2) Cleanliness of sand}

a) Purpose

The degree of sand cleanliness is obtained by the test of sand equivalent, which is a standardized test NF EN 933-8 [8]. The purpose of the sand equivalent test is to determine the degree of cleanliness of a sand. It defines the proportion of raw sand compared to impurities contained in the sand.

\section{b) Principle}

The sand equivalent is obtained by pouring a given mass of sand into two burettes containing a wash solution in order to evaluate in percentage the proportion of raw sand compared to impurities in the sand. The Sand Equivalent (SE) is calculated from the expression (2).

$$
\mathrm{SE}=\frac{h_{1}}{h_{2}} * 100
$$

With $h_{1}(\mathrm{~cm})$ the height of visible sand deposit and $h_{2}(\mathrm{~cm})$ the total height (including the fines in suspension).

\section{c) Equipment}

- A stirrer

- A washing tube

- Burettes

- A timer

\section{3) Specific unit weight of aggregates}

\section{a) Purpose}

The specific unit weight is obtained by the normalized test NF P 18 - 555 [9]. The purpose of the test is to express the mass per volume unit of aggregates particles without taking into account the volume occupied by the voids.

\section{b) Principle}

The specific unit weight of a body is generally obtained by measuring the volume of a given liquide (generally water) that the aggregate moves when it is poured into the liquid. The results of the absolute density are calculated by the expression (3). 


$$
\varphi_{A b s}=\frac{M s}{V_{2}-V_{1}}
$$

With $M s$ the mass of aggregates, $V_{1}$ the volume of water in the burette without the aggregates, $V_{2}$ the volume of water in the burette after the pouring of aggregates.

c) Equipment

- A burette

- A weighing machine

\subsubsection{Tests on Concrete}

\section{1) Consistency}

a) Purpose

The consistency of concrete is obtained by the standardized test NF P 18 - 45 [10]. The purpose of the test is to obtain the workability of the concrete so as to make its setting up and implementation easier.

\section{b) Principle}

The consistency is obtained by measuring the subsidence of fresh concrete under its own weight in the Abrams' cone.

\section{c) Equipment}

- Abrams' cone

\section{2) Compressive strength}

\section{a) Purpose}

The compressive strength of concrete is obtained by the standardized test NF P 18 - 406 [11]. The test is aimed to determine the compressive strength of concrete.

\section{b) Principle}

The test consists of submitting a standardized concrete test tube to an axial compressive force up to its ruin.

\section{c) Equipment}

- Mechanical press.

\section{Results and Interpretation}

\subsection{Results of Tests on Aggregates}

\subsubsection{Particle Size Analysis}

The particle size composition was obtained according to the norm NF EN 933 1 presented previously. The results of that test are presented in Tables 2-5 and in Figure 1 for natural sand, recylcled sand, natural gravels 5/25 and recycled gravels $5 / 25$.

From Table 2 and Table 3, we find out that the fine module of natural sand is 2.5 while that of recycled sand is 3.3. Those results show that recycled sand is very coarse since its finesse module is superior to 2.8 . The recycled aggregates-based concrete has lost its workability. In order to perform its workability, we are required to increase the proportion of sand fine particles so that the finesse module be comprised between 2.2 and 2.8 . 
Table 2. Particle size composition of natural sand.

\begin{tabular}{|c|c|c|c|c|c|c|c|}
\hline \multicolumn{2}{|c|}{$\begin{array}{c}\text { Siever } \\
\text { Number }\end{array}$} & \multicolumn{2}{|c|}{$\begin{array}{l}\text { Openning } \\
\text { (in } \mathrm{mm} \text { ) }\end{array}$} & \multicolumn{2}{|c|}{$\begin{array}{c}\text { Cumulative } \\
\text { Retained Particles }\end{array}$} & \multirow{2}{*}{$\begin{array}{c}\text { Passing } \\
\text { Particles } \\
(\%)\end{array}$} & \multirow[t]{2}{*}{ Observation } \\
\hline ASTM & AFNOR & ASTM & AFNOR & (g) & (\%) & & \\
\hline $3 "$ & 50 & 76.2 & 80 & & & & \\
\hline $21 / 2 "$ & 49 & 63.5 & 63 & & & & \\
\hline $2 "$ & 48 & 50.8 & 50 & & & & \\
\hline 11/2" & 47 & 38.1 & 40 & & & & \\
\hline $11 / 4^{\prime \prime}$ & 46 & 31.7 & 31.5 & & & & \\
\hline $1 "$ & 45 & 25.4 & 25 & & & & \\
\hline $3 / 4 "$ & 44 & 19.1 & 20 & & & & \\
\hline $2 / 3^{\prime \prime}$ & 43 & 16.9 & 16 & & & & \\
\hline $1 / 2 "$ & 42 & 12.7 & 12.5 & & & & \\
\hline $3 / 8^{\prime \prime}$ & 41 & 9.52 & 10 & & & & \\
\hline $1 / 3^{\prime \prime}$ & 40 & 7.93 & 8 & & & & \\
\hline $1 / 4 "$ & 39 & 6.35 & 6.3 & & & 100 & \\
\hline $3 / 16^{\prime \prime}$ & 38 & 4.76 & 5 & 16 & 1 & 99 & \\
\hline 5 & 37 & 4 & 4 & 34 & 2 & 98 & \\
\hline 6 & 36 & 3.36 & 3.15 & 58 & 3 & 97 & \\
\hline 8 & 35 & 2.38 & 2.5 & 98 & 5 & 95 & \\
\hline 10 & 34 & 2 & 2 & 150 & 7 & 93 & \\
\hline 12 & 33 & 1.68 & 1.6 & 247 & 12 & 88 & \\
\hline 16 & 32 & 1.19 & 1.25 & 409 & 20 & 80 & \\
\hline 18 & 31 & 1 & 1 & 617 & 31 & 69 & \\
\hline 20 & 30 & 0.84 & 0.8 & 826 & 41 & 59 & \\
\hline 30 & 29 & 0.59 & 0.63 & 1086 & 54 & 46 & \\
\hline 35 & 28 & 0.5 & 0.5 & 1298 & 65 & 35 & \\
\hline 40 & 27 & 0.4 & 0.4 & 1466 & 73 & 27 & \\
\hline 50 & 26 & 0.315 & 0.315 & 1599 & 80 & 20 & \\
\hline 60 & 25 & 0.25 & 0.25 & 1737 & 87 & 13 & \\
\hline 70 & 24 & 0.2 & 0.2 & 1811 & 91 & 9 & \\
\hline 100 & 23 & 0.16 & 0.16 & 1867 & 93 & 7 & \\
\hline 120 & 22 & 0.125 & 0.125 & 1900 & 95 & 5 & \\
\hline 140 & 21 & 0.1 & 0.1 & 1921 & 96 & 4 & \\
\hline 200 & 20 & 0.08 & 0.08 & 1937 & 97 & 3 & \\
\hline
\end{tabular}


Table 3. Particle size composition of recycled sand.

\begin{tabular}{|c|c|c|c|c|c|c|c|}
\hline \multicolumn{2}{|c|}{$\begin{array}{c}\text { Siever } \\
\text { Number }\end{array}$} & \multicolumn{2}{|c|}{$\begin{array}{l}\text { Openning } \\
\text { (in } \mathrm{mm} \text { ) }\end{array}$} & \multicolumn{2}{|c|}{$\begin{array}{c}\text { Cumulative } \\
\text { Retained Particles }\end{array}$} & \multirow{2}{*}{$\begin{array}{c}\text { Passing } \\
\text { Particles }\end{array}$} & \multirow[t]{2}{*}{ Observation } \\
\hline AFNOR & ASTM & AFNOR & (g) & (g) & (\%) & & \\
\hline $3 "$ & 50 & 76.2 & 80 & & & & \\
\hline 21/2" & 49 & 63.5 & 63 & & & & \\
\hline $2 "$ & 48 & 50.8 & 50 & & & & \\
\hline $11 / 2 "$ & 47 & 38.1 & 40 & & & & \\
\hline $11 / 4^{\prime \prime}$ & 46 & 31.7 & 31.5 & & & & \\
\hline $1 "$ & 45 & 25.4 & 25 & & & & \\
\hline $3 / 4 "$ & 44 & 19.1 & 20 & & & & \\
\hline $2 / 3^{\prime \prime}$ & 43 & 16.9 & 16 & & & & \\
\hline $1 / 2 "$ & 42 & 12.7 & 12.5 & & & & \\
\hline $3 / 8^{\prime \prime}$ & 41 & 9.52 & 10 & & & & \\
\hline $1 / 3^{\prime \prime}$ & 40 & 7.93 & 8 & & & & \\
\hline $1 / 4 "$ & 39 & 6.35 & 6.3 & & & & \\
\hline $3 / 16^{\prime \prime}$ & 38 & 4.76 & 5 & 0 & 0 & 100 & \\
\hline 5 & 37 & 4 & 4 & 194 & 10 & 90 & \\
\hline 6 & 36 & 3.36 & 3.15 & 392 & 20 & 80 & \\
\hline 8 & 35 & 2.38 & 2.5 & 614 & 30 & 70 & \\
\hline 10 & 34 & 2 & 2 & 798 & 40 & 60 & \\
\hline 12 & 33 & 1.68 & 1.6 & 962 & 48 & 52 & \\
\hline 16 & 32 & 1.19 & 1.25 & 1101 & 55 & 45 & \\
\hline 18 & 31 & 1 & 1 & 1226 & 61 & 39 & \\
\hline 20 & 30 & 0.84 & 0.8 & 1332 & 67 & 33 & \\
\hline 30 & 29 & 0.59 & 0.63 & 1442 & 72 & 28 & \\
\hline 35 & 28 & 0.5 & 0.5 & 1531 & 76 & 24 & \\
\hline 40 & 27 & 0.4 & 0.4 & 1607 & 80 & 20 & \\
\hline 50 & 26 & 0.315 & 0.315 & 1689 & 84 & 16 & \\
\hline 60 & 25 & 0.25 & 0.25 & 1752 & 87 & 13 & \\
\hline 70 & 24 & 0.2 & 0.2 & 1798 & 90 & 10 & \\
\hline 100 & 23 & 0.16 & 0.16 & 1851 & 92 & 8 & \\
\hline 120 & 22 & 0.125 & 0.125 & 1912 & 95 & 5 & \\
\hline 140 & 21 & 0.1 & 0.1 & 1933 & 97 & 3 & \\
\hline 200 & 20 & 0.08 & 0.08 & 1972 & 98 & 2 & \\
\hline
\end{tabular}


Table 4. Particle size composition of natural gravels 5/25.

\begin{tabular}{|c|c|c|c|c|c|c|c|}
\hline \multicolumn{2}{|c|}{$\begin{array}{l}\text { Siever } \\
\text { Number }\end{array}$} & \multicolumn{2}{|c|}{$\begin{array}{l}\text { Openning } \\
\text { (in } \mathrm{mm} \text { ) }\end{array}$} & \multicolumn{2}{|c|}{$\begin{array}{c}\text { Cumulative } \\
\text { Retained Particles }\end{array}$} & \multirow{2}{*}{$\begin{array}{c}\begin{array}{c}\text { Passing } \\
\text { particles }\end{array} \\
(\%)\end{array}$} & \multirow[t]{2}{*}{ Observation } \\
\hline AFNOR & ASTM & AFNOR & (g) & (g) & $(\%)$ & & \\
\hline $3 "$ & 50 & 76.2 & 80 & & & & \\
\hline $21 / 2^{\prime \prime}$ & 49 & 63.5 & 63 & & & & \\
\hline $2 "$ & 48 & 50.8 & 50 & & & & \\
\hline $11 / 2 "$ & 47 & 38.1 & 40 & & & & \\
\hline $11 / 4^{\prime \prime}$ & 46 & 31.7 & 31.5 & & & & \\
\hline $1 "$ & 45 & 25.4 & 25 & & & & \\
\hline $3 / 4 "$ & 44 & 19.1 & 20 & 0 & 0 & 100 & \\
\hline $2 / 3^{\prime \prime}$ & 43 & 16.9 & 16 & 446 & 10 & 90 & \\
\hline $1 / 2 "$ & 42 & 12.7 & 12.5 & 1854 & 42 & 58 & \\
\hline $3 / 8^{\prime \prime}$ & 41 & 9.52 & 10 & 3058 & 69 & 31 & \\
\hline $1 / 3^{\prime \prime}$ & 40 & 7.93 & 8 & 3655 & 82 & 18 & \\
\hline $1 / 4 "$ & 39 & 6.35 & 6.3 & 4209 & 95 & 5 & \\
\hline $3 / 16^{\prime \prime}$ & 38 & 4.76 & 5 & 4323 & 97 & 3 & \\
\hline 5 & 37 & 4 & 4 & 4426 & 100 & 0 & \\
\hline 6 & 36 & 3.36 & 3.15 & & & & \\
\hline 8 & 35 & 2.38 & 2.5 & & & & \\
\hline 10 & 34 & 2 & 2 & & & & \\
\hline 12 & 33 & 1.68 & 1.6 & & & & \\
\hline 16 & 32 & 1.19 & 1.25 & & & & \\
\hline 18 & 31 & 1 & 1 & & & & \\
\hline 20 & 30 & 0.84 & 0.8 & & & & \\
\hline 30 & 29 & 0.59 & 0.63 & & & & \\
\hline 35 & 28 & 0.5 & 0.5 & & & & \\
\hline 40 & 27 & 0.4 & 0.4 & & & & \\
\hline 50 & 26 & 0.315 & 0.315 & & & & \\
\hline 60 & 25 & 0.25 & 0.25 & & & & \\
\hline 70 & 24 & 0.2 & 0.2 & & & & \\
\hline 100 & 23 & 0.16 & 0.16 & & & & \\
\hline 120 & 22 & 0.125 & 0.125 & & & & \\
\hline 140 & 21 & 0.1 & 0.1 & & & & \\
\hline 200 & 20 & 0.08 & 0.08 & & & & \\
\hline
\end{tabular}


Table 5. Particle size composition of recycled du gravels 5/25.

\begin{tabular}{|c|c|c|c|c|c|c|c|}
\hline \multicolumn{2}{|c|}{$\begin{array}{c}\text { Siever } \\
\text { Number }\end{array}$} & \multicolumn{2}{|c|}{$\begin{array}{l}\text { Openning } \\
\text { (in } \mathrm{mm} \text { ) }\end{array}$} & \multicolumn{2}{|c|}{$\begin{array}{l}\text { Cumulated } \\
\text { retained }\end{array}$} & \multirow{2}{*}{$\begin{array}{c}\text { Passing } \\
(\%)\end{array}$} & \multirow{2}{*}{ Observation } \\
\hline AFNOR & ASTM & AFNOR & (g) & (g) & (\%) & & \\
\hline $3 "$ & 50 & 76.2 & 80 & & & & \\
\hline 21/2" & 49 & 63.5 & 63 & & & & \\
\hline $2 "$ & 48 & 50.8 & 50 & & & & \\
\hline $11 / 2 "$ & 47 & 38.1 & 40 & & & 100 & \\
\hline $11 / 4^{\prime \prime}$ & 46 & 31.7 & 31.5 & 289 & 11 & 89 & \\
\hline $1 "$ & 45 & 25.4 & 25 & 596 & 24 & 76 & \\
\hline $3 / 4 "$ & 44 & 19.1 & 20 & 1065 & 42 & 58 & \\
\hline $2 / 3^{\prime \prime}$ & 43 & 16.9 & 16 & 1505 & 60 & 40 & \\
\hline $1 / 2 "$ & 42 & 12.7 & 12.5 & 1859 & 74 & 26 & \\
\hline $3 / 8^{\prime \prime}$ & 41 & 9.52 & 10 & 2115 & 84 & 16 & \\
\hline $1 / 3^{\prime \prime}$ & 40 & 7.93 & 8 & 2307 & 92 & 8 & \\
\hline $1 / 4 "$ & 39 & 6.35 & 6.3 & 2430 & 97 & 3 & \\
\hline $3 / 16^{\prime \prime}$ & 38 & 4.76 & 5 & 2473 & 98 & 2 & \\
\hline 5 & 37 & 4 & 4 & 2492 & 99 & 1 & \\
\hline 6 & 36 & 3.36 & 3.15 & & & & \\
\hline 8 & 35 & 2.38 & 2.5 & & & & \\
\hline 10 & 34 & 2 & 2 & & & & \\
\hline 12 & 33 & 1.68 & 1.6 & & & & \\
\hline 16 & 32 & 1.19 & 1.25 & & & & \\
\hline 18 & 31 & 1 & 1 & & & & \\
\hline 20 & 30 & 0.84 & 0.8 & & & & \\
\hline 30 & 29 & 0.59 & 0.63 & & & & \\
\hline 35 & 28 & 0.5 & 0.5 & & & & \\
\hline 40 & 27 & 0.4 & 0.4 & & & & \\
\hline 50 & 26 & 0.315 & 0.315 & & & & \\
\hline 60 & 25 & 0.25 & 0.25 & & & & \\
\hline 70 & 24 & 0.2 & 0.2 & & & & \\
\hline 100 & 23 & 0.16 & 0.16 & & & & \\
\hline 120 & 22 & 0.125 & 0.125 & & & & \\
\hline 140 & 21 & 0.1 & 0.1 & & & & \\
\hline 200 & 20 & 0.08 & 0.08 & & & & \\
\hline
\end{tabular}




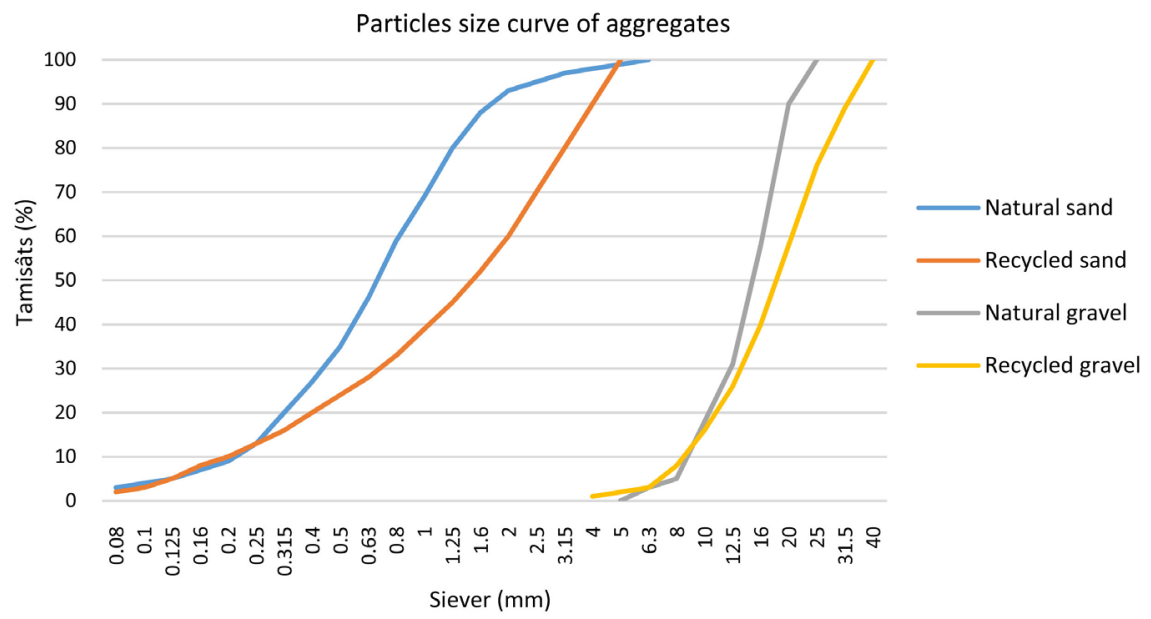

Figure 1. Particle size curve of aggregates.

\subsubsection{Sand Cleanliness}

The test of sand cleanliness showed that for natural sand, the visual sand equivalent (VSE) is around 70\%, while the sand equivalent to piston is $67.6 \%$ (SEP). For recycled sand, the respective values are $76.9 \%$ and $78 \%$. These results show that the recycled sand is clean and suitable for concrete.

\subsubsection{Specific unit Weight of Aggregates}

Table 6 presents the different values of specific unit weight of aggregates.

Specific unit weights of recycled aggregates are inferior to those of natural aggregates. This is due to the fact that recycled aggregates, which are porous, contain some quantity of cement still bounding on the aggregates on the one hand, and the nature of the original rock of the aggregates on the other.

\subsection{Results of Tets on Concretes}

\subsubsection{Composition of Concretes}

DreuxGoris method [12] was used. Concrete composition is presented in Table 7. Table 8 presents the equivalent composition.

\subsubsection{Equivalent Composition}

See Table 8.

\subsubsection{Consistency Test}

The results of subsidence test to Abrams' cone are presented in Table 9.

The different concretes are plastic since their maneuverability is comprised in the interval between $5 \mathrm{~cm}$ and $9 \mathrm{~cm}$. The maneuverability of reference concrete is $7 \mathrm{~cm}$ while that of recycled aggregates-based concrete is $9 \mathrm{~cm}$. There has been observed the necessity in additional water for recycled aggregates-based concrete in order to obtain the same workability as that of the reference concrete. This shows up the need for additional water in recycled aggregates. The results presented in the Table 9 show that the formulated concretes can be used to build formwork footings, retaining walls, slabs, pavement, beams and columns. 
Table 6. Specific unit weight of aggregates.

\begin{tabular}{ccccc}
\hline Aggregates & Natural sand & Recycled sand & Natural gravels & Recycled gravels \\
\hline Specific unit weight $\left(\mathrm{g} / \mathrm{cm}^{3}\right)$ & 2.5 & 2.38 & 2.78 & 2.38 \\
\hline
\end{tabular}

Table 7. Concrete composition (per cubic meter).

\begin{tabular}{|c|c|c|c|c|}
\hline \multirow{2}{*}{ Concrete } & \multicolumn{4}{|c|}{ Composition } \\
\hline & Cement (kg) & Sand (kg) & Gravels (kg) & Water $(\mathrm{kg})$ \\
\hline $\begin{array}{c}\text { Reference concrete (Ref) } \\
\text { [Natural sand, natural gravels] }\end{array}$ & 350 & 450 & 825 & 170 \\
\hline $\begin{array}{c}\text { Recycled concrete } 1\left(\mathrm{RC}_{1}\right) \\
\text { [Natural sand, recycle gravels] }\end{array}$ & 350 & 450 & 825 & 170 \\
\hline $\begin{array}{c}\text { Recycled concrete } 2\left(\mathrm{RC}_{2}\right) \\
\text { [Recycle sand, natural gravels] }\end{array}$ & 350 & 450 & 825 & 170 \\
\hline $\begin{array}{c}\text { Recycled concrete } 3\left(\mathrm{RC}_{3}\right) \\
\text { [Recycle sand, recycle gravels] }\end{array}$ & 350 & 450 & 825 & 170 \\
\hline
\end{tabular}

Table 8. Concrete composition on cylindrical $16 * 32 \mathrm{~cm}$ test-tubes.

\begin{tabular}{|c|c|c|c|c|}
\hline \multirow{2}{*}{ Concrete } & \multicolumn{4}{|c|}{ Composition } \\
\hline & Cement $(\mathrm{kg})$ & Sand $(\mathrm{kg})$ & Gravels (kg) & Water $(\mathrm{kg})$ \\
\hline $\begin{array}{c}\text { Reference concrete (Ref) } \\
\text { [Natural sand, natural gravels] }\end{array}$ & 6.25 & 11.25 & 20.625 & 4.25 \\
\hline $\begin{array}{c}\text { Recycled concrete } 1\left(\mathrm{RC}_{1}\right) \\
\text { [Natural sand, recycle gravels] }\end{array}$ & 6.25 & 11.25 & 20.625 & 4.25 \\
\hline $\begin{array}{c}\text { Recycled concrete } 2\left(\mathrm{RC}_{2}\right) \\
\text { [Recycle sand, natural gravels] }\end{array}$ & 6.25 & 11.25 & 20.625 & 4.25 \\
\hline $\begin{array}{c}\text { Recycled concrete } 3\left(\mathrm{RC}_{3}\right) \\
\text { [Recycle sand, recycle gravels] }\end{array}$ & 6.25 & 11.25 & 20.625 & 4.25 \\
\hline
\end{tabular}

Table 9. Results of the subsidence test.

\begin{tabular}{ccccc}
\hline Concrete & Ref & $\mathrm{RC}_{1}$ & $\mathrm{RC}_{2}$ & $\mathrm{RC}_{3}$ \\
\hline Subsidence in cm & 5 & 9 & 9 & 7 \\
\hline
\end{tabular}

\subsubsection{Compressive Strength}

The results of the compressive strength test on $16 * 32 \mathrm{~cm}$ cylindrical test-tubes of the different concrete samples are presented in Table 10. The concrete samples were formulated by Dreux-Gorisse Method.

\section{Conclusion}

In order to contribute to construction waste management and environmental protection, it has been studied the properties of concrete formulated by recycled aggregates for its usage in building. The global aim was to analyze the influence of substitution of natural aggregates by recycled aggregates from building 
Table 10 . Compression test results on $16^{*} 32 \mathrm{~cm}$ cylindrical test-tubes.

\begin{tabular}{cc}
\hline Concrete & Compression resistance (MPa) \\
\hline $\mathrm{Ref}$ & 25.8 \\
$\mathrm{RC}_{1}$ & 18.17 \\
$\mathrm{RC}_{2}$ & 17.25 \\
$\mathrm{RC}_{3}$ & 21.5 \\
\hline
\end{tabular}

concrete demolition. The compressive strength of recycled aggregates-based concrete was acceptable compared to the natural aggregates-based concrete. The difference is due to the quality of structural concrete used as aggregates source. These mechanical properties show that recycled aggregates can produce concrete of strengths range between 20 and $25 \mathrm{MPa}$ without using any particular sophisticated technology. Usage of recycled aggregates in concrete formulation can offer a sure and helpful solution to demolition waste management. Concrete produced from recycled aggregates is likely to be used for structures of average span and in conditions of low aggressively. However, the study of recycled concrete micro-structure and their durability can complete and improve this study. Such a study can extend the usage range of recycled aggregates-based concrete in civil engineering.

\section{Conflicts of Interest}

The authors declare no conflicts of interest regarding the publication of this paper.

\section{References}

[1] Charef, A. (2007) La problématique des granulats au Maroc. Push-Button Publishing.

[2] Fraj, A.B. and Idir, R. (2017) Concrete Based on Recycled Aggregates-Recycling and Environmental Analysis: A Case Study of Paris' Region. Construction and Bulding Materials, 157, 952-964. https://doi.org/10.1016/j.conbuildmat.2017.09.059

[3] Wirquin, E., Hadjieva-Zaharieva, R. and Buyle-Bodin, F. (2000) Utilisation de l'absorption d'eau des bétons comme critères de leur durabilité: Application aux bétons de granulats recyclés. Materials and Structures, 33, 403-408. https://doi.org/10.1007/BF02479650

[4] Courard, L., Michel, F. and Delhez, P. (2010) Use of Concrete Road Recycled Aggregates for Roller Compacted Concrete. Construction Building Material, 24, 390-395. https://doi.org/10.1016/j.conbuildmat.2009.08.040

[5] Buyle-Bodin, F. and Zaharieva, R.H. (2002) Influence of Industrially Produced Recycled Aggregates on Flow Properties of Concrete. Materials and Structures, 35, 504-509. https://doi.org/10.1007/BF02483138

[6] Hussain, H. and Levacher, D. (2003) Recyclage de béton de démolition dans la fabrication des nouveaux bétons. Rencontres Universitaires de Génie Civil, La Rochelle, France.

[7] NF EN 933-1 (2012) Essais pour déterminer les caractéristiques géométriques des granulats, partie 1: Détermination de la granularité-analyse granulométrique par 
tamisage. AFNOR, Paris.

[8] NF EN 933-8 (1999) Essais pour déterminer les caractéristiques géometriques des granulats Partie 8; Evaluation des fines-Equivalent de sable. AFNOR, Paris.

[9] NF P 18-555 (1990) Granulats: Mesures des masses volumiques, de la porosité, du coefficient d'absorption et de la teneur en eau du sable. AFNOR, Paris.

[10] NF P 18-451 (1990) Béton frais: Essai d'affaissement au cône. AFNOR, Paris.

[11] NF P 18-406 (1981) Essai de compression des éprouvettes en béton durci. AFNOR, Paris.

[12] Dreux, G. and Festa, J. (1998) Nouveau guide du béton et ses constituants. Edition Eyrolles, $8^{\text {eme }}$ édition, $409 \mathrm{p}$. 